\title{
MENIMBANG PERIHAL KEKERASAN DALAM RUMAH TANGGA (KDRT) DENGAN KITAB KUNING
}

\section{Oleh: \\ Reza Ahmad Zahid*}

\begin{abstract}
Abstrak
Islam mengangkat derajat wanita pada martabat yang sangat tinggi dan mulia. Ketika era Jahiliyah memposisikan wanita seperti barang yang tidak berharga, Islam hadir dengan membawa kehormatan bagi kaum wanita. Islam telah mengatur hak dan kewajiban bagi para suami dan istri sehingga keseimbangan dapat terjadi dalam sebuah rumah tangga. Seorang suami tidak bisa serta merta memposisikan dirinya sebagai orang yang super power sehingga memperdayakan seorang istri dengan seenaknya. Jika seorang suami hendak mengingatkan kepada istri yang nusyuz, maka dia harus mengingatkan dengan cara yang telah diatur oleh agama Islam, yakni dengan tingkah laku atau ucapan yang mendidik. Apabila terjadi kekerasan dalam rumah tangga yang menimpa kepada seorang istri maka seorang istri berhak untuk mengangkat permasalahan ke pengadilan atau dengan cara penyelesaian diluar pengadilan.
\end{abstract}

Kata Kunci: Kekerasan dalam Rumah Tangga (KDRT), Kitab Kuning.

\section{Pendahuluan}

Dewasa ini kekerasan terhadap perempuan terus mengalami peningkatan walaupun telah dilakukan beberapa upaya dari seluruh lapisan masyarakat untuk menanggulanginya. Akan tetapi tampaknya pelaku kekerasan pun tidak merasa takut akan penegakan hukum yang telah dilakukan. Hal ini dikarenakan adanya pandangan masyarakat bahwa perempuan adalah makhluk yang lebih rendah dibandingkan oleh laki-laki yang mempunyai kedudukan yang lebih tinggi. Adanya

\footnotetext{
${ }^{*}$ Institut Agama Islam Tribakti (IAIT) Kediri
} 
strukturalisasi dalam masyarakat itu menimbulkan adanya ketimpangan atau ketidakadilan jender. Ketimpangan jender adalah perbedaan peran dan hak antara perempuan dan laki-laki di masyarakat yang menempatkan perempuan dalam status lebih rendah dari laki-laki. "Hak istimewa" yang dimiliki laki-laki ini seolah-olah menjadikan perempuan sebagai "barang" milik lakilaki yang berhak untuk diperlakukan semena-mena, termasuk dengan cara kekerasan. ${ }^{1}$ Pandangan masyarakat ini telah menghapus hak-hak dari perempuan baik dalam rumah tangga maupun lingkungan yang sejatinya ada. Kekerasan yang dialami oleh perempuan tidak hanya dijumpai di dalam lingkungan masyarakat tetapi juga dapat ditemukan dalam lingkungan rumah tangga.

\section{Pengertian KDRT}

Indonesia sebagai negara hukum mempunyai kewajiban untuk menegakkan keadilan dan mencegah terjadinya kejahatan di masyarakat termasuk kekerasan terhadap perempuan khususnya kekerasan dalam rumah tangga yang bersifat tertutup. Sifat ketertutupan dari kekerasan rumah tangga ini yang menyebabkan banyak kasus yang tidak pernah terungkap di dalam masyarakat. Kekerasan dalam rumah tangga (KDRT) kerap dianggap wajar oleh masyarakat. ${ }^{2}$ Pandangan ini disebabkan kebudayaan atau sistem partiarkhi yang telah mengakar di masyarakat, dimana laki-laki semenjak lahir telah ditanamkan pemikiran bahwa mereka berkuasa atas istri-istri mereka karena kekuasaan yang mereka miliki tidak mempunyai batasan dalam lingkup rumah tangga. Kekuasaan dalam rumah tangga yang di dapat kaum laki-laki menjadikan perempuan sebagai tempat pelampiasan kekuasaan mereka. Kekerasaan atau violence dalam pengertian umum adalah tindakan agresi dan

${ }^{1}$ Hak istimewa adalah hak yang dimiliki laki-laki yang merupakan hasil dari pemikiran sistem patriarkhi yang menempatkan laki-laki sebagai penguasa keluarga, mempunyai kedudukan yang superior, mempunyai hak dominasi dan eksploitasi atas istri-istri mereka. Redaksi Kesrepro, 24 Desember 2007 15:53, Kekerasan Terhadap Perempuan, dalam http://www. kesrepro.info/?q=taxanomy/term/2

${ }^{2}$ Nunuk A Prasetyo. 2002.Gerakan Anti Kekerasan Terhadap Perempuan. Yogyakarta: Kanisius. Hal. 24. 
pelanggaran yang menyebabkan atau dimaksudkan untuk menyebabkan penderitaan atau menyakiti orang lain, binatang dan harta benda. ${ }^{3}$

Berdasarkan Deklarasi Persatuan Bangsa-Bangsa (PBB) tentang Kekerasan Terhadap Perempuan (1993), yang dimaksud dengan kekerasan adalah: "Setiap tindakan yang berakibat atau memungkinkan berakibat kesengsaraan atau penderitaan secara fisik, seksual, atau psikologis termasuk ancaman, pemaksaan, perampasan kemerdekaan secara sewenang-wenang yang terjadi di depan umum atau dalam kehidupan pribadi."

Dari pengertian di atas kekerasan terhadap perempuan dapat menyebabkan kesengsaraan atau penderitaan, hal ini jelas melanggar hak asasi manusia. Dalam Pasal 45 Undang-undang Nomor 39 tahun 1999 tentang Hak Asasi Manusia menyebutkan bahwa "hak wanita dalam undang-undang ini adalah hak asasi manusia". Dengan demikian setiap pasal yang merupakan hak asasi manusia di undang-undang tersebut juga merupakan hak dari perempuan sebagai individu di dalam masyarakat. Perempuan memiliki hak untuk tidak menerima kekerasan dalam bentuk apapun yang merupakan pelanggaran hak asasi manusia.

Realita kekerasan terhadap perempuan yang mengalami peningkatan setiap tahun mencapai titik yang mengkhawatirkan. Kekerasan terhadap perempuan paling banyak terjadi di rumah tangga dengan pelaku suami. Jika setiap lapisan masyarakat tidak berupaya memutus rantai kekerasan mulai dari sekarang dikhawatirkan hal ini akan merusak generasi penerus bangsa. Undang-undang RI Nomor 23 tahun 2004 tentang Penghapusan Kekerasan Dalam Rumah Tangga menyatakan bahwa yang dimaksud dengan kekerasan dalam rumah tangga adalah:

"Setiap perbuatan terhadap seseorang, terutama perempuan, yang berakibat penderitaan secara fisik dan

\footnotetext{
${ }^{3}$ Wikipedia Bahasa Indonesia, Kekerasan, dalam http//id.wikipedia.org/wiki /kekerasan\# ,

${ }^{4}$ Pusat Kajian Wanita dan Gender UI. Hak Azasi Perempuan Instrumen Hukum untuk Mewujudkan Keadilan Gender. Jakarta: Yayasan Obor Indonesia. 2004. Hal. 66

${ }^{5}$ Undang-undang Nomor 39 tahun 1999 tentang Hak Asasi Manusia.
} 
seksual atau penelantaran rumah tangga termasuk ancaman untuk melakukan perbuatan, pemaksaan, perampasan kemerdekaan secara melawan hukum dalam lingkup rumah tangga (Pasal 1)." 6

\section{Batasan KDRT}

Kekerasan dalam rumah tangga menurut pengertian di atas dapat dikelompokkan berdasarkan bentuk perbuatan pelaku, yaitu:

1. kekerasan fisik

Kekerasan fisik adalah perbuatan yang mengakibatkan rasa sakit, jatuh sakit atau luka berat (Pasal 6).

2. kekerasan psikologis

Kekerasan psikologis adalah perbuatan yang mengakibatkan ketakutan, hilangnya rasa percaya diri, hilangnya kemampuan untuk bertindak, rasa tidak berdaya, dan/atau penderitaan psikis berat pada seseorang (pasal 7)

3. Kekerasan seksual

Kekerasan seksual adalah setiap perbuatan yang berupa pemaksaan hubungan seksual, pemaksaan hubungan seksual dengan cara tidak wajar dan/atau tidak disukai, pemaksaan hubungan seksual dengan orang lain untuk tujuan komersial dan/atau tujuan tertentu.Kekerasan seksual meliputi (pasal 8):

a. Pemaksaan hubungan seksual yang dilakukan terhadap orang yang menetap dalam lingkup rumah tangga tersebut;

b. Pemaksaan hubungan seksual terhadap salah seorang dalam lingkup rumah tangganya dengan orang lain untuk tujuan komersial dan/atau tujuan tertentu.

\section{Kekerasan ekonomi atau penelantaran.}

Penelantaran rumah tangga adalah seseorang yang menelantarkan orang dalam lingkup rumah tangganya, padahal menurut hukum yang berlaku baginya atau karena persetujuan atau perjanjian ia wajib memberikan kehidupan, perawatan, atau pemeliharaan kepada orang tersebut. Selain itu, penelantaran juga berlaku bagi setiap orang yang mengakibatkan

${ }^{6}$ Undang-undang No 23 tahun 2004 tentang Penghapusan Kekerasan Dalam Rumah Tangga. 
ketergantungan ekonomi dengan cara membatasi dan/atau melarang untuk bekerja yang layak di dalam atau di luar rumah sehingga korban berada di bawah kendali orang tersebut (pasal 9).

Dalam satu kasus kekerasan yang terjadi di lingkup rumah tangga yang dialami perempuan sebagai istri sering dijumpai tidak hanya satu bentuk kekerasan yang mereka alami bahkan dalam banyak penelitian yang telah dilakukan oleh para pemerhati perempuan yang menemukan korban mengalami semua bentuk kekerasan selama pernikahan. Keadaan ini yang mendorong banyak perempuan berjuang untuk membela hakhak mereka selama pernikahan. Mereka kini semakin berani membuat keputusan untuk bercerai dari suami mereka, jika terjadi kekerasan dalam rumah tangga. Perempuan korban KDRT senantiasa bertumpu pada Pengadilan Agama untuk melepaskan diri dari jeratan kekerasan yang menimpanya. ${ }^{7}$

Orang laki-laki bisa dikatakan ujung tombak bagi wanita dalam kehidupan berumah tangga, oleh sebab itu Alloh SWT. Berfirman dalam surat An-nisa' ayat 34

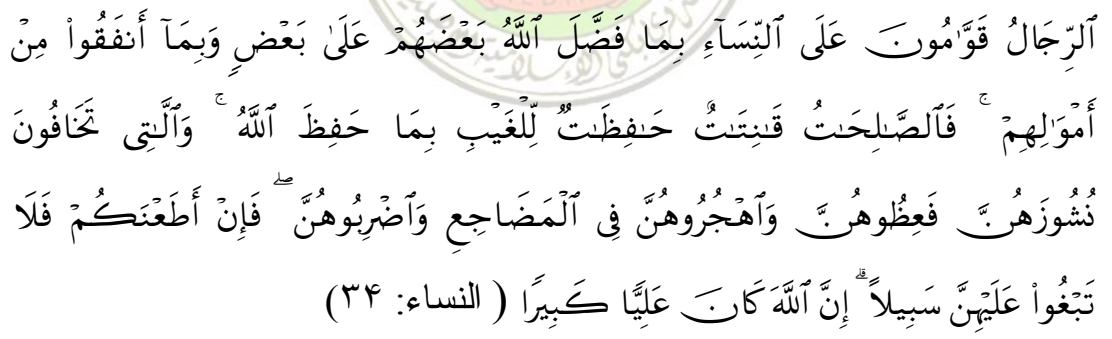

Terjemahnya : Kaum laki-laki itu adalah pemimpin bagi kaum wanita, oleh Karena Allah Telah melebihkan sebahagian mereka (laki-laki) atas sebahagian yang lain (wanita), dan Karena mereka (lakilaki) Telah menafkahkan sebagian dari harta mereka. sebab itu Maka wanita yang saleh, ialah yang taat kepada Allah lagi memelihara diri ${ }^{8}$ ketika suaminya tidak ada, oleh Karena

${ }^{7}$ Ari. Sejarah Pelayanan Terpadu Bagi Korban Kekerasan Berbasis Gender Di Indonesia Graha Perempuan Edisi 17 Juni 2008 Hal. 3

${ }^{8}$ Maksudnya: tidak berlaku curang serta memelihara rahasia dan harta suaminya. 
Allah Telah memelihara (mereka) ${ }^{9}$. wanitawanita yang kamu khawatirkan nusyuznya ${ }^{10}$, Maka nasehatilah mereka dan pisahkanlah mereka di tempat tidur mereka, dan pukullah mereka. Kemudian jika mereka mentaatimu, Maka janganlah kamu mencari-cari jalan untuk menyusahkannya.Sesungguhnya Allah Maha Tinggi lagi Maha besar.

Walaupun laki-laki sebagai pemimpin wanita ia tidak diperkenankan berbuat seenaknya sendiri tanpa ada suatu batas dan aturan, bahkan ia dianjurkan/wajibkan untuk bergaul dengan istrinya dengan cara yang baik, apabila terjadi prilaku atau ucapan istri yang tidak sesuai dengan keinginan suami dan dilarang oleh agama hendaklah bagi suami untuk mengingatkan istrinya dengan tiga cara/metode yang harus berurutan:

1. Hendaklah bagi suami menasehati istrinya dengan cara yang lembut dan baik, seperti: wahai istriku jadilah kamu istri yang solihah.

2. Hendaklah bagi suami pisah ranjang dengan istrinya. Cara yang kedua ini apabila prilaku dan ucapannya si istri masih tetap tidak berubah, apabila si istri sudah merubah prilakunya maka cara ini sudah tidak lagi dibutuhkan cukup dengan cara yang pertama saja.

3. Hendaklah bagi suami memukul istrinya dengan syarat :

a. Pukulannya tidak pada wajah

b. Pukulannya tidak sampai membekas

c. Pukulannya tidak menggunakan alat keras

d. Pukulannya tidak menyakitkan

e. Pukulannya tidak sampai menyebabkan hilangnya suatu kemanfatannya anggota tubuh. Apabila sampai menghilangkan kemanfaatan tubuh maka hendaknya si isri untuk melaporkan suaminya pada pihak yang berwajib.

9 Maksudnya: Allah Telah mewajibkan kepada suami untuk mempergauli isterinya dengan baik

${ }^{10}$ Nusyuz: yaitu meninggalkan kewajiban bersuami isteri. nusyuz dari pihak isteri seperti meninggalkan rumah tanpa izin suaminya 
Cara yang ketiga ini berlaku apabila cara yang kedua tidak dapat merubah prilaku dan ucapan istri yang tidak dikenankan suami dan agama. ${ }^{11}$

Dan cara yang di atas apabila suami menyangka bahwa cara tersebut bisa bermanfaat bagi isrtinya, apabila tidak bermanfaat hendaklah bagi suami untuk melaporkan pada hakim bagian urusan pernikahan, agar hakim mencari dua juru damai dari dua pihak (pihak suami dan istri) jika suami dan istri masih menginginkan untuk damai. Hal tersebut sesuai dengan firman Alloh SWT. Dalam surat an-nisa' ayat 35 :

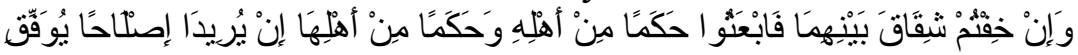

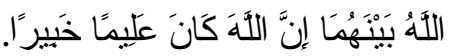

Terjemahnya : Dan jika kamu khawatirkan ada persengketaan antara keduanya, Maka kirimlah seorang hakam ${ }^{12}$ dari keluarga laki-laki dan seorang hakam dari keluarga perempuan. jika kedua orang hakam itu bermaksud mengadakan perbaikan, niscaya Allah memberi taufik kepada suami-isteri itu. Sesungguhnya Allah Maha mengetahui lagi Maha Mengenal.

Bagi suami diperbolehkan membuat jerah istri, apabila istrinya melakuakan perbuatan yang dilarang/diharamkan agama seperti halnya bagi sayyid (tuan/majikan) diperbolehkan membuat jerah budaknya. Uraian di atas tadi merupakan merupakan ketentuan hukum dari Alloh SWT. yang telah dipaparkan didalam kitab Al-qur'an. ${ }^{13}$

Sementara itu Nabi Muhammad SAW bersabda:

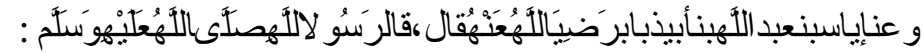

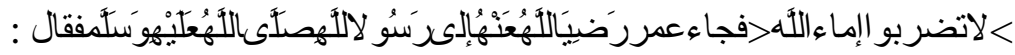

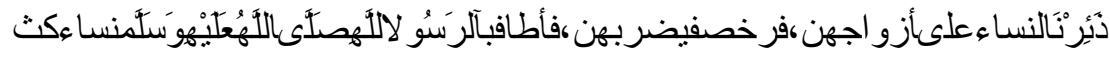

${ }^{11}$ Muhammad Nawawi bin Umar al-Jawi ,Qutul habib al-ghorib., dar al-kutub, hal. 332

${ }^{12}$ Hakam ialah juru pendamai.

${ }^{13}$ Ali Ahmad al-Jarjawi , Hikmah at-tasyri' wa falsafatuhu,, dar alkutub, juz.02, hal. 29. 


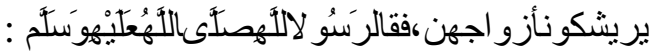 >لقدأطافبآلمحدنسا عكثيريشكو نأزو اجهنليسأو لئكبخيار كم>رو اهأبو داو دبإسنادصحيح}

Artinya : Dari lyas bin Abdullah bin Abu Dzubab r.a., katanya: "Rasulullah s.a.w. bersabda:"Janganlah engkau semua memukul hamba-hamba Allah yang perempuan - maksudnya suami jangan memukul isterinya." Umar r.a. lalu datang kepada Rasulullah s.a.w. lalu bersabda: "Para isteri itu berani menentang pada suami-suaminya." Oleh sebab itu beliau s.a.w. memberikan kelonggaran untuk memukul mereka yang tidak keras sampai menyakitkan. Selanjutnya beberapa kaum wanita sama berkeliling mendatangi keluarga Rasulullah untuk mengadukan para suaminya - kerana ada beberapa isteri yang dipukul suaminya. Kemudian Rasulullah s.a.w. bersabda: "Benar-benar telah berkeliling beberapa kaum wanita mendatangi keluarga Muhammad untuk mengadukan perihal suami-isterinya. Maka bukannya suami-suami yang sedemikian itu yang termasuk orang-orang pilihan di antara engkau semua - kaum mu'minin." Diriwayatkan oleh Imam Abu Dawud dengan isnad shahih. ${ }^{14}$

Dari sini jelas dapat dibedakan antara ketegasan dan hukuman dengan KDRT, sebab KDRT merupakan tindakan yang berlebihan dari ukuran dan ketetapan syari'at. Oleh karena itu hendaklah dilihat kembali semua kasus KDRT yang ada, menimbangknya dengan syari'at Islam yang memiliki kelengkapan dan keindahan, sehingga tidak salah dalam memutuskan dan menyimpulkannya. Terlebih pada zaman jauhnya kaum muslimin dari agamanya dan isu-isu kesamaan gender sedang dipropagandakan pada semua sendi untuk semakin menjauhkan kaum muslimin dari agamanya.

Dari penjelasan di atas, bisa disimpulkan beberapa contoh yang bisa dikategorikan sebagai KDRT, antara lain: 146.

${ }^{14}$ Syekh Muhyiddin,Riyadhussolihin, Semarang:Thoha putra,Hal 145- 
1. Menjadikan pukulan atau hajr sebagai jalan pertama dalam menyelesaikan masalah rumah tangga.

2. Mengeluarkan kata-kata yang tidak baik, seperti qabbahakillah (semoga Allah menjadikanmu jelek).

2. Mendiamkan isteri di luar rumah tanpa keperluan.

3. Memukul wajah.

4. Memukul di luar batas kewajaran.

\section{Penyelesaian KDRT}

Penyelesaian kasus kekerasan dalam rumah tangga sebenarnya dapat ditempuh dengan jalur pengadilan dan luar pengadilan. Penyelesaian yang ditempuh oleh para pihak akan berpengaruh pada keutuhan rumah tangga. Setiap penyelesaian yang ditempuh mempunyai kelemahan dan kelebihan. Dalam penyelesaian kasus di dalam pengadilan baik menggunakan proses pidana maupun persidangan perceraian mempunyai kelebihan adanya kepastian hukum bagi para pihak akan tetapi disini keutuhan rumah tangga rentan dipertahankan, hal ini berbanding terbalik jika memilih penyelesaian di luar pengadilan, kemungkinan mempertahankan keutuhan dalam rumah tangga lebih besar tetapi dalam kepastian hukum kurang mengikat para pihak dan sewaktu-waktu dimungkinkan pelaku melakukan kekerasan lagi.

Alternative Dispute Resolution (alternatif penyelesaian sengketa) atau yang lebih dikenal dengan penyelesaian di luar pengadilan berdasarkan Pasal 1 angka 10 Undang-undang No 30 tahun 1999 tentang arbitrase dan alternatif penyelesaian sengketa, menyebutkan bahwa: "Alternatif penyelesaian sengketa adalah suatu pranata penyelesaian sengketa di luar pengadilan, atau dengan cara mengesampingkan penyelesaian secara litigasi di Pengadilan Negeri". 15

Alternative Dispute Resolution (ADR) adalah suatu prinsip penyelesaian sengketa di luar pengadilan dengan cepat dan biaya murah. ADR merupakan salah satu mekanisme

15 Pasal 1 angka 10 Undang-undang No 30 Tahun 1999 tentang Arbitrase dan Alternatif Penyelesaian Sengketa. 
penyelesaian sengketa yang efektif, efesien, dan menguntungkan untuk berbagai pihak di masa yamg akan datang. ${ }^{16}$

Alternative Dispute Resolution Mempunyai banyak bentuk yang dapat ditempuh oleh para pihak yang bersengketa. Dalam undang- undang No 30 tahun 1999 terdapat lima bentuk penyelesaian di luar pengadilan yaitu: konsultasi, negosiasi, mediasi, konsiliasi, dan pendapat ahli. Para pihak yang bersengketa biasanya menggunakan satu atau lebih penyelesaian di luar pengadilan untuk menyelesaikan kasus mereka. Sama halnya dalam kasus kekerasan di rumah tangga banyak pihak yang menggunakan jalur penyelesaian di luar pengadilan atau damai dengan salah satu bentuk alternatif penyelesaian sengketa. Karena berdasarkan penelitian dari berbagai LSM para korban akan menempuh jalur peradilan jika telah berulangkali mengalami kekerasan dalam rumah tangga. Dengan demikian sebelum mereka melapor mereka teleh berusaha menggunakan upaya penyelesaian di luar pengadilan untuk memperbaiki hubungan rumah tangga. Namun tampaknya karena ada pergeseran pola pikir di dalam masyarakat membuat upaya damai di luar pengadilan tidak banyak membuahkan hasil. Hal ini lah yang menarik untuk dikaji bagaimana karakteristik kasus dan para pihak dalam kasus kekerasan dalam rumah tangga serta ketika awal terjadi kekerasan alasan apa yang mendasari korban menggunakan penyelesaian di luar pengadilan dan mengapa akhirnya banyak korban yang memilih menggunakan penyelesaian di pengadilan yang memungkinkan mereka harus mengorbankan keutuhan rumah tangganya.

Ingatlah syari'at islam tidak membolehkan dan tidak mensyariatkan kecuali untuk kebaikan manusia seluruhnya, dan tidak melarang kecuali perkara yang merusak dan mengganggu manusia. Karena itu, marilah kembali merujuk kepada Islam dalam melihat dan mengamalkan semua amalan keseharian kita. Sebagai penutup kita perlu memperhatikan dua hal dibawah ini.

Pertama, Sabar Menghadapi Isteri. Bahtera rumah tangga tidak dapat berjalan dengan baik jika pasangan suami isteri tidak

${ }^{16}$ Suyud Margono, 2004, ADR dan Arbitrase Proses Pelembagaan dan Aspek Hukum, Bogor: Ghalia Indonesia. Hal 5. 
memiliki kesabaran di antara mereka. Dalam hal ini Rasulullah Shallallahu 'alaihi wa sallam bersabda:

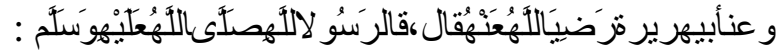

$$
\begin{aligned}
& \text { > لايفر كمؤمنمؤمنة، إنكر همنهاخلقأر ضيمنها آخر أوقالغير ه>رَوَ اهُمُسْلِّه. }
\end{aligned}
$$

Artinya : "Janganlah seorang mukmin membenci mukminah. Jika ia tidak suka dengansalah satu perangainya, tentu ia suka perangai yang lainnya" [Muslim, $]^{17}$

Tidak semestinya suami menjadikan setiap kesalahan istri sebagai sebab untuk melampiaskan amarah. Hendaklah kita mencontoh Rasulullah Shallallahu 'alaihi wasallam yang oleh isteri beliau, 'Aisyah Radhiyallahu 'anha disifati sebagai berikut:

$$
\begin{aligned}
& \text { حدثناه أبو كريب, حدثثا أبو أسامة عن هشام عن ابيه عن عائشة قالت: ما ضرب }
\end{aligned}
$$

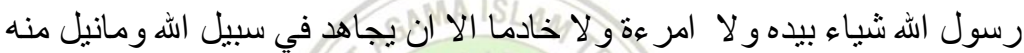

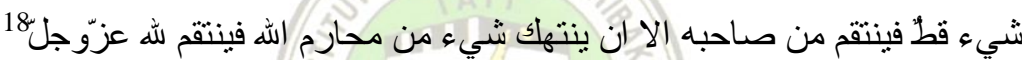

Artinya : "Rasulullah Shallallahu 'alaihi wa sallam, sama sekali tidak pernah memukul sesuatu dengan tangan beliau, tidak juga pernah memukul wanita atau pembantu, kecuali dalam jihad fi sabilillah. Dan tidaklah beliau pernah disakiti kemudian membalas dendam; tetapi jika salah satu larangan Allah dilanggar, beliau membalas karena Allah" [HR Muslim, 2328]

Al-Alusi rahimahullah berkata: "Dan jelas, bahwasanya menahan diri dan sabar terhadap isteri lebih baik daripada memukul mereka, kecuali jika ada alasan yang kuat". ${ }^{19}$

Kedua, Islam Menghormati dan Memuliakan Wanita.Keterangan di atas menunjukkan bahwa Islam melarang KDRT, kecuali jika diperlukan untuk mewujudkan maslahat yang lebih besar, dan dengan batasan-batasan yang ketat. Hal seperti ini, kita istilahkan dengan ketegasan. Islam memberikan kedudukan sangat mulia kepada wanita. Banyak hal yang menunjukkan penghormatan tersebut.

\footnotetext{
${ }^{17}$ Syekh Muhyiddin,Riyadhussolihin, Semarang:Thoha putra,Hal 147.

${ }^{18}$ Abi al-husein,Shahih Muslim,Bairut,Dar al-fikri,Hal 413.

19 Rûhul-Ma'ani, 3/23

${ }^{17}$ Syekh Muhyiddin,Riyadhussolihin, Semarang:Thoha putra,Hal 145.
} 
Nabi Shallallahu 'alaihi wa sallam menjadikan orang yang paling baik dalam umatini ialah yang paling baik memperlakukan isterinya. Beliau Shallallahu 'alaihi wa sallam bersabda:

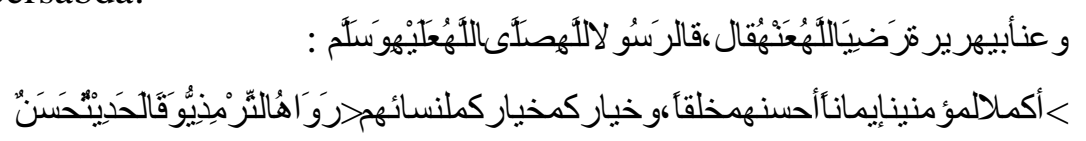

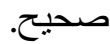

Artinya : "Orang mukmin yang paling sempurna imannya ialah yang terbaik akhlaknya; dan orang-orang terbaik di antara kalian ialah yang paling baik akhlaknya terhadap isteri mereka" [HR at-Tirmidzi,. Dishahihkan Syaikh al-Albâni dalam Silsilah alAhadits ash-Shahîhah, $]^{20}$

Hadits-hadits ini hendaklah menjadi pendorong munculnya rasa takut pada diriseorang muslim. Komitmen sebagian muslimin terhadap pokok-pokok ajaranAhlus-Sunnah terkadang tidak diiringi dengan akhlak yang baik, termasuk kepadakeluarga, khususnya isteri. KDRT masih sering terdengar dari rumah kita.Padahal Nabi Shallallahu 'alaihi wa sallam menjadikan hal ini sebagai parameterkedudukan kita di sisi Allah. Yang tidak berakhlak baik kepada isteri bukanlahgolongan terbaik dalam umat ini.

\section{Kesimpulan}

Undang-undang RI Nomor 23 tahun 2004 tentang Penghapusan Kekerasan Dalam Rumah Tangga menyatakan bahwa yang dimaksud dengan kekerasan dalam rumah tangga adalah: "Setiap perbuatan terhadap seseorang, terutama perempuan, yang berakibat penderitaan secara fisik dan seksual atau penelantaran rumah tangga termasuk ancaman untuk melakukan perbuatan, pemaksaan, perampasan kemerdekaan secara melawan hukum dalam lingkup rumah tangga (Pasal 1)." Kekerasan dalam rumah tangga menurut pengertian di atas dapat dikelompokkan berdasarkan bentuk perbuatan pelaku, yaitu:

1. kekerasan fisik 
2. kekerasan psikologis

3. kekerasan seksual

4. kekerasan ekonomi atau penelantaran.

Beberapa contoh yang bisa dikategorikan sebagai KDRT, antara lain:

1. Menjadikan pukulan atau hajr sebagai jalan pertama dalam menyelesaikan masalah rumah tangga.

2. Mengeluarkan kata-kata yang tidak baik, seperti qabbahakillah (semoga Allah menjadikanmu jelek).

3. Mendiamkan isteri di luar rumah tanpa keperluan.

4. Memukul wajah.

5. Memukul di luar batas kewajaran.

Penyelesaian kasus kekerasan dalam rumah tangga sebenarnya dapat ditempuh dengan jalur pengadilan dan luar pengadilan. Penyelesaian yang ditempuh oleh para pihak akan berpengaruh pada keutuhan rumah tangga. Setiap penyelesaian yang ditempuh mempunyai kelemahan dan kelebihan. Dalam penyelesaian kasus di dalam pengadilan baik menggunakan proses pidana maupun persidangan perceraian mempunyai kelebihan adanya kepastian hukum bagi para pihak akan tetapi disini keutuhan rumah tangga rentan dipertahankan, hal ini berbanding terbalik jika memilih penyelesaian di luar pengadilan, kemungkinan mempertahankan keutuhan dalam rumah tangga lebih besar tetapi dalam kepastian hukum kurang mengikat para pihak dan sewaktu-waktu dimungkinkan pelaku melakukan kekerasan lagi.

Sebagai penutup kita perlu memperhatikan dua hal dibawah ini, demi terciptanya keluarga yang sakinah, mawaddah, warahmah:

Pertama, Sabar Menghadapi Isteri dan Kedua, Islam Menghormati dan Memuliakan Wanita. Keterangan di atas menunjukkan bahwa Islam melarang KDRT, kecuali jika diperlukan untuk mewujudkan maslahat yang lebih besar, dan dengan batasan-batasan yang ketat. 


\section{DAFTAR PUSTAKA.}

Redaksi Kesrepro, 24 Desember 2007 15:53, Kekerasan Terhadap Perempuan, dalam http://www. kesrepro.info/?q=taxanomy/term/2

Prasetyo, Nunuk A. Gerakan Anti Kekerasan Terhadap Perempuan. Yogyakarta: Kanisius. 2002.

Wikipedia Bahasa Indonesia, Kekerasan, dalam http//id.wikipedia.org/wiki /kekerasan\#

Pusat Kajian Wanita dan Gender UI, Hak Azasi Perempuan Instrumen Hukum untuk Mewujudkan Keadilan Gender. Jakarta: Yayasan Obor Indonesia. 2004.

Undang-undang Nomor 39 tahun 1999 tentang Hak Asasi Manusia.

Undang-undang No 23 tahun 2004 tentang Penghapusan Kekerasan Dalam Rumah Tangga.

Ari, Sejarah Pelayanan Terpadu Bagi Korban Kekerasan Berbasis Gender Di Indonesia, Graha Perempuan. 2008

Muhammad nawawi bin umar al-jawi,Qutul habib al-ghorib., dar al-kutub,

Hikmah at-tasyri' wa falsafatuhu, ali ahmad al-jarjawi, dar alkutub, juz.02,

Pasal 1 angka 10 Undang-undang No 30 Tahun 1999 tentang Arbitrase dan Alternatif Penyelesaian Sengketa.

Margono ,Suyud, ADR dan Arbitrase Proses Pelembagaan dan Aspek Hukum, Bogor: Ghalia Indonesia. Rûhul-Ma'ani, 2004

Syekh Muhyiddin, Riyadhussolihin, Semarang:Thoha Putra. 2000. 
Muslim, Abi al-Husein, Shahih Muslim, Bairut: Dar al-fikri 2007 